\title{
Local Culture in Environmental Conservation: An Ecocritical Overview of a Novel Set in Meratus Mountains, South Kalimantan
}

\author{
Derri Ris Riana ${ }^{*}$, Jahdiah $^{2}$, Rissari Yayuk ${ }^{3}$ \\ 1, 2, ${ }^{3}$ Balai Bahasa Provinsi Kalimantan Selatan. \\ "Corresponding author. Email: derri.ris@ kemdikbud.go.id
}

\begin{abstract}
Environmental issues that we face today encourage efforts to increase ecological awareness. The green literature movement is used as a medium to raise awareness by voicing criticism of the environment. This movement highlights the increasing environmental damage along with the anthropocentric perspective on the exploitation of nature for the sake of fulfilling needs and profits. In this case, local culture plays a role in environmental conservation strategies in South Kalimantan. This study aims to explore the local culture of the Dayak Meratus community, which plays a role in ecological conservation strategies of the novel set in Meratus Mountains, South Kalimantan. This study uses a qualitative descriptive method using an ecocritical approach. The research data are the novel written by Aliman Syahrani, Palas, and the novel written by Eva Liana Mawinei. The steps of work are to classify data, analyze, and conclude. The results showed that two novels set in the Meratus Mountains, namely: Palas and Mawinei (1) describe the local culture of human relations with nature in the form of the recital of natural signs; (2) perform a ritual of gratitude towards nature; (3) use nature wisely for the necessities of life and living equipment, such as housing and means of transportation; and has customary rules in the form of a forest ban and (4) a ban on cutting certain trees. This local culture needs to be preserved to conserve the environment in the Meratus Mountains, South Kalimantan, amid natural exploitation that impacts the environmental crisis.
\end{abstract}

Keywords: green literature, local culture, environmental conservation, ecocritic.

\section{INTRODUCTION}

The threat to the environmental crisis has become a real problem for the world, including Indonesia at this time. According to Indonesian Forum for the Environment (Wahana Lingkungan Hidup Indonesia/Walhi) in the National Conference on the Environment on December 13, 2017, Indonesia has been in an ecological emergency with environmental damage. This damage was caused by monopoly activities that control natural resources that are not environmentally friendly, impacting livelihood sources [1]. An unavoidable ecological disaster characterizes an environmental emergency due to an environmental crisis exacerbated by climate change. Throughout 2020, Badan Nasional Penanggulan Bencana/ National Disaster Management Agency data showed 4650 disaster events in Indonesia consisting of floods (1.518), tornadoes (1.386), landslides (1.054), forest and land fires (597), tidal waves, and abrasion (43), drought (26), earthquake (18), and volcanic eruption (7) [2]. This ecological disaster is increasingly threatening human survival.

The urgency of ecological awareness becomes important when the related parties must preserve environmental humans. The more exploitation of natural resources is allowed, the more suffering will be for humans, especially those who do not have power over the management of natural resources. Privatization of natural resources for the benefit of corporations and capitalist industry increasingly benefits certain parties, while others suffer. An anthropocentric perspective that makes the environment an object to be exploited further exacerbates environmental changes. In this case, literary studies with the philosophy of taking sides with the environment are important to build ecological insight and ecological ethics in a literary manner without judging [3]. With the power of stories and imaginations rich in symbols, literature is an effective medium in 
instilling the character of love for the environment. Naning Pranoto and Sides Sudyarto DS initiated the green literature movement in the Raya culture website to raise ecological awareness and voice the movement to care for the earth [4]. This environmental awareness movement is carried out by uploading literary works, either in poetry or short stories, creative writing competition, and creative writing training, especially on the environmental theme.

The literary movement in favor of the environment began to develop in various parts of Indonesia with the increasingly critical environmental changes portrayed by the authors. Authors who have a certain ecological topography background have their peculiarities in expressing their imagination. Typical environmental dictions emerge from the author's environment. For example, literature born from an environment dominated by forests will appear diction about trees. Writers often describe ecological change and climate change according to their scope or region to reflect typical environmental dictions, such as hot, cool, slum [5]. Dictions typical of the environment also appear in literary works from South Kalimantan writers who voice their environmental criticism. The topography of South Kalimantan, which is dominated by rivers and forests, raises criticism of the environment through ecological dictions that are not far from rivers and forests, namely river pollution, tree cutting, forest fires, and illegal mining.

The environmental crisis in South Kalimantan, especially the Meratus Mountains area, which has emerged in various ecological disasters, has been highlighted by South Kalimantan writers in their works. The emergence of the Save Meratus movement was driven by efforts to save the Meratus Mountains area from coal mining exploitation activities and the expansion of oil palm land, which impacted the threat of an environmental crisis. To support the Save Meratus movement, South Kalimantan writers carried out various activities, namely publishing literary works in poetry, short stories, and novels, conducting book review discussions, and performing environmentalthemed poetry to increase ecological awareness of the threat of an environmental crisis in the Meratus Mountains. Ecological awareness is also carried out by echoing the local culture of the Meratus Dayak people who live in the Meratus Mountains in preserving nature in literary works.

Nature for the Meratus Dayak community is home and source of livelihood. The closeness to nature can be seen in environmental ethics, manifested in customary rules and rituals that have existed since the predecessors until passed down to the next generation. The form of respect for nature is shown in the religious system in the form of kaharingan, which gives offerings to certain trees in the forest which are believed to dwell ancestral spirits. Ritual offerings to nature in the form of Bawanang ceremony or aruh ganal are carried out to give thanks for the abundant harvest and the implementation of traditional rituals before huma tugal farming activity. A traditional ritual is a form of the closeness of the Meratus Dayak community to nature. Customary rites that support environmental conservation are also seen in the prohibition of logging in certain tree species and the division of sacred forest areas and forbidden forests prohibiting forest use to remain sustainable.

Local culture has an important role in preserving the environment of the Meratus Mountains, especially the Dayak Meratus community. Therefore, the researcher is necessary to conduct eco-critical research to describe the local culture of Dayak Meratus in the novel set in the Meratus Mountains, South Kalimantan, due to its strategic role in environmental conservation. This study will be known as environmental ethics in the relations between Dayak Meratus community and nature and the customary rules of Dayak Meratus in protecting and caring for nature through literary works in the form of a novel that raises the background of The Meratus Mountains. This study examines Aliman Syahrani's novel Palas and Eva Liana's novel Mawinei which describes the environmental ethics of the Dayak Meratus community in the Meratus Mountains setting. Palas was written by Aliman Syahrani and published by Publisher Pustaka Banua in 2004. This novel tells the story of the ecological changes and environmental ethics of the Dayak Meratus tribe. The male character, who is the main character in this novel, is involved in a dam construction project in the Loksado area, which used to be his childhood place, before moving to Kandangan. This novel is dominated by the disclosure of the natural landscape and the culture of Dayak Meratus people in the Loksado area, the slopes of the Meratus Mountains. The character's inner struggle against environmental changes and the exotic culture of Dayak Meratus dominate the plot of this novel. Meanwhile, Mawinei was written by Eva Liana and published by Zukzezexpress in 2017. The novel, which is set in Manakili Village, the slopes of the Meratus Mountains, tells the story of the struggles of Mawinei's character in realizing his dream to become a doctor amid obstacles to access to education and costs natural conditions, and the Dayak Meratus culture. Like Palas, Mawinei also describes the environmental changes and environmental ethics of the Dayak Meratus tribe.

Ecocritical research on literary works in the South Kalimantan region has been published in several writings. The article of Riana [6] entitled "The Environmental Crisis in Kalimantan in the Collection of the Eternal Longing for Borneo Poetry" explores the environmental crisis in Kalimantan in Greg Garrad's eco-critical poetry works in the form of river pollution, forest destruction, natural disasters, and the extinction of typical Kalimantan animals. Pranoto [4] entitled "The Role of Mother Language as a Pillar of Green Literature: Exploring the Philosophy of Local Wisdom Protecting the Earth of South Kalimantan" explores the role of the mother tongue in protecting the earth of South Kalimantan due to environmental destruction through local wisdom in proverbs that developed in the 
Banjar community. Hatmiati [7], in her article entitled "Ecological genius in Banjar Pemali," analyzes Banjar pemali, which functions as a medium for environmental conservation, respecting animal rights, and ethics in social life. In this study, the analysis focuses on the local culture of the Meratus Dayak community in helping to preserve nature by revealing environmental ethics and customary rules that support the care of the Meratus Mountains environment in the novel set in the Meratus Mountains.

\section{LITERATURE REVIEW}

Environmental issues are not only a concern in the field of science but also the humanities. The emergence of ecocritical studies as an interdisciplinary study between ecology and literature is based on the involvement of literature to play a role in solutions to save the environment. The term ecocriticism was first introduced in 1978 by William Rueckert in an essay entitled Literature and Ecology: An Experiment in Ecocriticism. Other terms used include ecopuitika, environmental literary criticism, and green cultural studies. The work area of ecocriticism reveals an awareness of the limitations of the environment on the impact of human behavior in destroying the basic life support systems of the earth [8]. Ecocritic studies are increasingly widespread, with environmental-themed conferences/seminars organized by the Association for the Study of Literature and the Environment (ASLE), a professional association related to literary and environmental studies that started in America expanding in the UK and Japan. This association organizes regular conferences and publishes journals, including literary analysis, creative writing, and articles on environmental activities and education [9].

Ecocritical studies explore the relationship between literature and the physical environment [8]. Foucault states that the human sciences, which include psychology, sociology, literature, and mythology, tend to look for models in the context of biology, economics, and linguistics [10]. Ecocriticism analyses literature by relating it to the environment. Literature can provide ecological insight and environmental ethics by describing ecological changes and crises through the power of stories with aesthetic language. Furthermore, literature is an effective medium in evoking conscience without judging, so environmental values are more easily internalized [3]. Thus, ecocritics can contribute more to raising social problems, especially ecology, by exploring and providing solutions to environmental change.

Ecocriticism follows the view of mimetic theory that literature cannot be separated from reality [10]. In this case, the fact expressed in the literary work is related to the environment in which the literary work was produced. The author's background becomes inseparable when he understands the criticism of the environment he wants to put forward. Ecocriticism studies the state of the literary environment when the environment influences the imagination, for example, a place to grow and develop, travel, and writers write to understand their works [8]. Writers will use symbols typical of the environment in their reach when they want to convey certain goals. Symbols in the form of trees, land, water, and rivers provide color to the literary works of South Kalimantan writers. The rivers and forests predominate the topographical environment. In this case, the relationship between the South Kalimantan authors' backgrounds in the literary works they produce is very close. Literary works in the area describe the anxiety about the environmental crisis in the Meratus Mountains, which has caused an ecological disaster in literary works in the form of poetry, short stories, and novels.

The literary works developed in South Kalimantan have contributed to increasing ecological insight and awareness and providing solutions to save the environment. One of the efforts to save the environment, which is also described in literary works, is to re-encourage local culture for its role in environmental preservation. This can be seen in Gary Snyder's writings entitled The Practice of the Wild (1990), an American eco-critical poet and writer, who stated that the American cultural memory of the natural agreement between humans and other creatures was important in stopping the destruction of the earth's wealth [11]. The local culture can be considered the peak of ecological awareness when people begin to live again with nature in the principle of balance. Humans need nature for survival, while nature needs humans for sustainability.

The local culture of Meratus Dayak, which lives in the Meratus Mountains region, has a harmonious relationship between humans and nature. Dayak Meratus people inhabit the Meratus Mountains area in South Kalimantan [12]. For them, nature is their 'home' and source of livelihood to support their survival. The closeness of the Dayak Meratus community to nature can be seen in cultural aspects, such as traditional rituals in religious systems, livelihood systems, systems of living equipment and technology, and customary rules that support environmental conservation. Ecocritic works on environmental ideas and representations that appear in the cultural space [5]. Local culture is an effort to prevent the widespread destruction of Meratus' nature due to the demands of the global economy, which only exploits natural resources.

\section{METHOD}

This research is qualitative research using an ecocritical approach. Ecocritic works on the relationship between literature and the physical environment to provide ecological awareness of the environmental crisis. The primary data used are two novels set in the Meratus Mountains, South Kalimantan, namely the novel written by Aliman Syahrani Palas, published by Publisher Pustaka Banua in 2004, and the novel written by Eva Liana Mawinei, published by Zukzezexpress in 2017. The two novels represent 
human closeness, especially the Dayak Meratus, with nature described by environmental ethics and customary rules that support ecological sustainability. The secondary data is also used to support research data, namely documents, various references related to research, and interviews with informants, namely the novelist of Aliman Syahrani and Eva Liana.

Data collection is done by literature study, as well as recording and note-taking techniques. Data analysis was carried out in several stages, namely:

1. classifying data in the novel of Palas and Mawinei related to the Meratus Mountains environment;

2. analyzing the data obtained based on environmental ethics and Dayak Meratus customary rules related to environmental sustainability; and

3. concluding the data in local culture in environmental conservation efforts in the two novels.

\section{RESULT AND DISCUSSION}

\subsection{The Form of Local Culture of Dayak Meratus Community and the Strategic Role in Conserving the Environment}

The problem of the environmental crisis, including the local culture of the people in South Kalimantan, especially Meratus Mountains, has become the attention of writers in South Kalimantan. The local culture includes ethics and customary rules for the environment. Through the depiction of imagination in the two novels set in the Meratus Mountains - the novel of Palas and Mawinei-the Dayak Meratus community has ethics and customary rules that are useful in environmental conservation efforts.

\subsubsection{Environmental Ethics of Dayak Meratus In Literary Imagination}

Buel, Heise, and Thornber in their article Literature and Environment, citing Gary Snyder's The Practice of the Wild (1990), stated that the American cultural memory of the natural agreement between humans and other creatures was important in stopping the destruction of the earth's wealth [11]. This study uses ecocriticism by analyzing local culture that is able to counteract the negative effects of industrial modernity as a tool to analyze the literary works studied. The local culture includes ethics and customary rules for the environment.

The environmental ethics of the Dayak Meratus people who live on the slopes of Meratus in preserving the environment are illustrated in literary works set in the Meratus Mountains. The Dayak Meratus community maintains harmony with nature through traditional rules and rituals passed down from previous generations to the next. Nature is a 'home' and a source of livelihood for the Dayak Meratus community. Respect for nature can be seen through the relationship between the Dayak community and nature by reading the signs of nature, performing a ritual of gratitude towards nature, using nature wisely for the necessities of life and living equipment, such as housing and transportation in utilizing nature.

In the two novels, which are set in the Meratus Mountains, the closeness of the Dayak Meratus community to nature can be seen in the belief in natural signs as clues to the occurrence of something that affects the community's survival. They believe that nature provides clues that something will happen if they can live in peace with nature. The ability to read natural signs to predict something is obtained from the experience of events that have occurred before. The Dayak Meratus people learn from natural events that have occurred so that they are finally able to obtain instructions in living life. One of the natural signs believed by the Dayak Meratus community is related to signs on plants. Rice storage behavior is used to predict crop yields in the coming year. The following is evidence of the closeness of the Dayak community to nature with their ability to read signs on plants to predict crop yields and seasonal changes in the coming year in Aliman Syahrani's novel Palas.

Keesokan harinya, cerita Duncan lagi, bakul-bakul yang terbuat dari anyaman bambu atau rotan yang berisi beras dikeluarkan dari dalam lalaya. Di situ akan ditemukan beberapa pertanda sebagai petunjuk nasib bagi warga balai di tahun-tahun mendatang. Apabila beras di dalam bakul terasa hangat, maka itu adalah sebagai pertanda bahwa hari-hari di sepanjang tahun mendatang akan dilalui penduduk balai dengan penuh suasana suka cita; hasil panen yang melimpah, musim yang bersahabat, dan keselamatan akan menyelimuti semua penghuni balai. Tetapi jika sebaliknya, bila beras dalam bakulbakul itu terasa dingin, pertanda hari-hari di sepanjang tahun mendatang akan diwarnai dengan berbagai kearalan dan masa paceklik; tanaman ladang diserang hama; kekurangan buah-buahan, kemarau terlalu panjang dan akan ada kematian [13].

The next day, Duncan's story again, baskets made of woven bamboo or rattan filled with rice were removed from the lalaya. There will be found several signs as a clue to the fate of the house residents in the years to come. If the rice in the basket feels 
warm, then it is a sign that the days of the coming year will be passed by the house residents full of joy; all residents of the house will get bountiful harvests, friendly seasons, and safety. But if on the other hand, if the rice in the baskets feels cold, it is a sign that the days of the coming year will be colored with various difficulties and times of famine; pests attack field crops; lack of fruits, drought is too long, and there will be death [13].

Dayak Meratus community uses rice storage conditions to detect the harvest and next year's harvest season. In a series of Bawanang/aruh ganal events as a form of gratitude for the abundant harvest throughout the year, there is a process of removing a basket filled with rice from the lalaya, a place to put offerings and crops. The signs on the rice condition in the basket are used as an indication of the yield. If the conditions are warm, it is believed that there will be an abundant harvest and a good season for farming activities next year. However, if the opposite condition is that the rice is cold, it is believed that there will be crop failure, a famine season, and a season that does not support farming activities. The ability to read natural signs is obtained because of the closeness of the community to nature.

For the Dayak community, especially the Dayak Meratus community, rice is a plant that is considered sacred and respected. The respect for rice can be seen in traditional rituals during farming activities/huma tugal rice plants, both from land clearing and harvesting. The traditional ritual is carried out so that the journey of rice life is safe from the beginning, planting, and harvesting. In the novel of Palas written by Aliman Syahrani, the series phases in the farming process are described as huma tugal from the phases of manabas, batabang, mamanduk, manugal, and mangatam. Traditional rituals are carried out before the planting process. This ritual is carried out as a form of request to the ancestral spirits to bless the journey of rice life so that it can grow well to avoid crop failure. The form of closeness to nature in the form of traditional rituals before engaging in religious activities can be seen in the following quote from Palas' novel.

Sebelum kegiatan manugal, terlebih dahulu dilaksanakan acara selamatan yang disebut bamula atau pamataan, bertempat di areal peladangan masing-masing dan dipimpin oleh seorang balian. Dalam ritual bamula atau pamataan ini sang balian mendaraskan mantera dan mamang untuk keberhasilan pelaksanaan huma tugal. Dalam ritual ini juga diadakan sejumlah sajen dan persembahan. Semua sajen dan persembahan itu diletakkan di dalam lalaya yang didirikan di tengah areal huma tugal. Lalaya dihiasi dengan janur kelapa muda atau janur enau dan bunga bayam warna merah darah. Di sekeliling lalaya dipagari dengan suligi dari buluh kuning yang ditancapkan ke tanah membentuk formasi khusus [13].

Before manugal, a
selamatan tradition event called
bamula or pamataan is held first,
taking place in their farming areas
and led by a balian. In this bamula or
pamataan ritual, the balian recites a
mantra and mamang for the
successful implementation of huma
tugal. In this ritual also held some
offerings. All the offerings are placed
in a lalaya which is set up in the
middle of the huma tugal area. Lalaya
is decorated with young coconut
leaves or palm leaves and blood red
spinach flowers. Around the lalaya it
is fenced with suligi from yellow
reeds that are plugged into the ground
to form a special formation [13].

The farming process of the Dayak Meratus community is covered by traditional rituals, both before the farming process, during the farming process, and after the farming process. From the quote, before manugal activity, bamula or pamataan is a traditional ritual carried out in fields where rice is to be planted. In the ritual led by the balian, a mantra is recited, and offerings are provided to ancestral spirits in order to bless the rice plants that will be planted so that later they will thrive. Furthermore, when the rice has started to grow and bear fruit, a traditional ritual called basambu is also performed during the farming process. This ritual is carried out so that the rice that has begun to grow can thrive so that the harvest does not fail. Meanwhile, after harvesting or the mangatam phase, a bawanang/aruh ganal ceremony is held, a thanksgiving for the harvest. The Dayak Meratus community's environmental ethic manifested at the bawanang ceremony as an expression of gratitude for the goodness of nature for an abundant harvest can be seen in the following quote from Palas' novel.

Menurut Duncan, upacara bawanang atau aruh ganal ini akan dilaksanakan selama enam malam berturut-turut yang diisi dengan rincian acara tertentu pula. Seperti pada malam kedua besok akan diisi dengan acara bapalas, yaitu penghormatan kepada lalaya dengan 
cara memercikkan darah sembelihan ayam di janur lalaya. Kemudian dilanjutkan dengan bakapur; membuat rajah-rajah di tubuh para penari yang diberi gelar para sakai, abdi-abdi sang balian, sebagai orang-orang yang ditugasi menyampaikan mamang-mamang kepada arwah para datu [13].

According to Duncan, Bawanang ceremony or aruh ganal will be held for six consecutive nights filled with details of certain events. As on the second night tomorrow will be filled with a bapalas event, which is a tribute to Lalaya by sprinkling the blood of the slaughtered chicken on the leaves of Lalaya. Then proceed with bakapur; make tattoos on the bodies of the dancers who are given the title of sakai, servants of the balian, as people who are tasked with delivering mamang-mamang to the spirits of the datu [13].

This customary ritual in the farming system adopted by Dayak Meratus community is a form of maintaining the principle of reciprocity with the environment. Nature has provided a source of livelihood for them. They also repay nature's kindness with an expression of gratitude through bawanang ritual. From the quote from Palas' novel, it is illustrated that bawanang is carried out routinely with a series of traditional rituals that have been prepared to honor the ancestral spirits through offerings for the fertility of the land planted with rice.

The form of environmental ethics of the Dayak Meratus community can also be seen in the wise use of nature. Although nature is used as the main source of livelihood for the Dayak Meratus people, they do not treat nature arbitrarily as an object that must be exploited on a large scale. Nature is used wisely by using natural resources according to needs, for example wood is used sufficiently as the main raw material to build a house. The shape of the house was built according to the topography of the Meratus area, which is dominated by rivers and forests. The house was built on high stakes to avoid flooding or attacks from wild animals. The adaptation of the Dayak Meratus community to the natural landscape of the Meratus Mountains which signifies a harmonious relationship with nature can be seen in the following quote from Palas' novel.

Rumah balai ini adalah demi memudahkan hidup mengelompok untuk kerja sama dan keamanan masyarakat suku Dayak. Rumah balai di atas tonggak tinggi juga berfungsi untuk menghindari genangan air pasang atau banjir serta serangan tiba-tiba dari binatang buas bagi mayoritas urang Bukit yang tinggal di pedalaman, atau pula dari musuh yang datangnya tak terduga. Selain itu, kolongnya juga mereka gunakan untuk kegiatan menumbuk padi dan memelihara binatang ternak [13].

This house is intended to facilitate group life for cooperation and security for Dayak community. The house on a high pillar also serves to avoid tidal puddles or floods and sudden attacks from wild animals for the majority of urang bukit who live in inland territory or from unexpected enemies. In addition, they also use the pit under the house for pounding rice and raising livestock [13].

The use of nature wisely is also shown in the use of living equipment under the needs of life and the topography of the Meratus environment, for example the use of transportation means such as lanting. Lanting is a piece of traditional equipment in the form of a raft made of bamboo. The river flow in the Meratus area encourages Meratus community to use river transportation. Therefore, the community uses the raw materials available in their area, namely bamboo to transport crops, such as candlenut and cinnamon. The river landscape with swift currents in the description of Palas's quote is responded to by the Dayak Meratus community utilizing river transportation in the form of lanting. Although made of bamboo, lanting can be used in the swift flow of the Amandit River with the skills of a raftman. This indicates that the Dayak Meratus community has lived in peace with nature, increasingly understanding how to treat nature wisely. The use of lanting as a means of transportation for the Dayak Meratus community can be seen in Palas' novel's following quote.

Uji keberanian
sesungguhnya adalah, jika tidak
gentar, meninggalkan Loksado lewat
Sungai Amandit. Mendengar gemuruh
suaranya saja, hati sudah
menguncup. Apalagi perjalanan
ditempuh dengan lanting, yakni rakit
bambu. Baru menapakkan kaki di
rakit saja sudah terasa keganasan
arusnya. Dalam sebentar, lanting
terpontang-panting dan terkadang
tertelan air. Si tukang rakit sibuk
mengendalikan dengan pinanjak atau
dayung bambu, sesekali terjun ke
sungai, menahan hempasan rakit dari
riam-riam tajam dan batu-batu besar


yang bertonjolan dari dasar sungai [13].

The real test of courage was, if not daunted, to leave Loksado via the Amandit River. Just hearing the roar of his voice, the heart is already closed. Moreover, the journey is taken by lanting, namely a bamboo raft. Just set foot on the raft already felt the ferocity of the current. In a moment, lanting is swayed and sometimes swallowed by water. The raftman is busy controlling with pinanjak or bamboo paddles, occasionally plunging into the river, resisting the crash of the raft from sharp cascades and large stones protruding from the riverbed [13].

The environmental ethics described in the literary imagination in Palas' novel is useful for saving the Meratus environment from massive exploitation of the natural resources contained in it. From the results of the analysis of the novel, the Dayak Meratus environmental ethics is manifested in the form of respect for nature through a harmonious relationship with nature by reading natural signs. Rice storage in baskets is used to detect future survival. The rice plant is considered a sacred plant because in the process of planting it is covered by traditional rituals. Environmental ethics can be seen in the implementation of traditional rituals during farming activities that aim to pray for the fertility of the land and rice plants by asking the spirits of the ancestors. After the last phase of farming activities, bawanang is carried out as an expression of gratitude to nature which has bestowed abundant harvests throughout the year. The use of nature wisely following the needs of life is also a form of environmental ethics for the Dayak Meratus community.

\subsubsection{Dayak Meratus Traditional Rules in Conserving the Environment}

As stated in Buel, Heise, and Thornber in their article Literature and Environment, local culture also supports ecocriticism in voicing the environmental crisis due to the adverse effects of industrial modernization. This cultural ecocriticism is used to analyze Palas and Mawinei's novels, which contain of Meratus Dayak customary rules in preventing forest destruction and preserving forest sustainability.

Through the depiction of imagination in the two novels set in the Meratus Mountains-Palas and Mawinei-Dayak Meratus people have customary rules useful in environmental conservation efforts. A life that is inseparable from nature forms local knowledge to preserve the environment for survival. This local knowledge is embodied in customary rules passed down orally from previous generations to the next. Even though it is not written, the Dayak Meratus community obeyed the customary rules because they are believed to be guidelines/guidance in carrying out life. Not infrequently, the rules are accompanied by sanctions for those who violate the rules. Customary rules related to environmental conservation can be seen in the existence of sacred forest areas and forbidden forests described in Eva Liana's novel Mawinei and the prohibition on cutting certain tree species in the Meratus forest described in Aliman Syahrani's novel Palas.

The division of sacred and forbidden forests in the Dayak Meratus customary rules is used as a guideline for forest management in the Meratus Mountains area. This division of territory can be used as a protector of forest sustainability because the forest is their life in providing a source of livelihood. Sacred forest or katuan keramat is a special place to bury ancestors. By customary agreement, the forest, located at the top of the hills, may only be used by Dayak Meratus community for funerals. Apart from burial purposes, this forest should not be used. If someone violates the use of the forest, for example, cutting down a tree, they will be subject to sanctions, fines, or plagues according to customary law. The description of forest management in the sacred forest can be seen in the following quote from the novel of Mawinei.

Mawinei mengkirik ngeri. Meski pengalaman serupa pernah ia lewati, namun cerita tentang tenggelamnya anak laki-laki amang Ungling dua hari yang lalu membuat bulu kuduknya merinding. Anak Amang Ungling, si Basmi, yang berusia lebih tua darinya, waktu itu baru pulang dari kebun karet milik uwaknya di Loklahung. Lalu terpeleset saat menyeberang di tengah hujan lebat begini pula. Basmi sebenarnya cukup pandai berenang. Namun, menurut Kakek Aban, kaki Basmi diseret datu penguasa Amandit. Jadi, palas, ganti nyawa, gara-gara Amang Ungling lupa mohon ampun dan mengirim sesajen karena khilaf menebang kayu di katuan keramat. Padahal hutan di daerah tersebut terlarang untuk dimanfaatkan, khusus untuk pemakaman para leluhur saja, serta dianggap sebagai daerah hunian para datu penjaga Meratus [14].

Mawinei groaned in horror. Even though he had a similar experience, the story about Amang Ungling's son's drowning two days ago made the chills down his spine. 
Amang Ungling's son, Basmi, who was older than him, had just returned from his uwak's rubber plantation in Loklahung. Then slipped while crossing in the pouring rain. Basmi is actually quite good at swimming. However, according to Grandpa Aban, Basmi's leg was dragged by the Amandit spirit. So, palas, change your life, because Amang Ungling forgot to ask for forgiveness and sent offerings because he made a mistake cutting wood in the katuan keramat. Even though the forest in the area is forbidden to be used, specifically for the funeral of the ancestors, and is considered a residential area for the Meratus datu guards [14].

From the quote, katuan keramat area can only be used for the burial of the ancestors. When the prohibition to cut down trees in katuan keramat is violated, the characters in the story are sure that there is a concequence from their behavior. The figure of Basmi is believed by Grandpa Aban, damang and balian who is a respected figure in Meratus Dayak community, the death of Basmi has been believed of the concequence of cutting down trees in katuan keramat area which is considered sacred. When he died in the river, the character of Basmi was considered to have been taken by an angry datu/ancestor. After cutting down trees in the forbidden area, Basmi's character should beg for forgiveness by bringing offerings to the area. This belief in katuan keramat protects the forest from exploitation, both internally and externally. Because there is no use of the forest other than for cemeteries, katuan keramat area preserves its biodiversity. Not surprisingly, the location of the forest on top of the mountain is beautiful and found by wild animals that are rarely found in other forest areas. The description of katuan keramat as a forest whose animals are still preserved can be seen in the following quote from Mawinei's novel.

"Kalau terus menunggu ..." Kaayat terlihat tegang. Mengingat beragam binatang buas di katuan karamat. Kalau hilangnya Winei di daerah pahumaan dan kabun gatah, tidak seberapa berbahaya. Yang dikhawatirkan adalah jika anak itu berlari menghindari api sampai ke katuan karamat di atas gunung. Di sana wilayah tak terjamah yang dipenuhi binatang buas. Hutan yang diperuntukkan khusus sebagai kuburan leluhur mereka [14].

"If you keep waiting..." Kaayat looked tensed. By realizing the variety of wild animals in Katuan Karamat. If Winei's disappearance in the Pahumaan and Kabun Gatah area, it's not that dangerous. What is worried is if the child runs away from the fire to the katuan karamat on the mountain. There was an unspoiled territory filled with wild beasts. Forests that are specifically designated as the graves of their ancestors [14].

The management of the forbidden area also helps protect Meratus forest. This area is a forest where the wood is not allowed to be cut, but the forest products can only be used. For example, suppose katuan keramat is not allowed to be managed at all because it is a special ancestral burial area. In that case, it is still permissible to manage it using forest products other than wood. With customary rules on managing forests like this, protected forests will remain sustainable so that they will be more useful in supporting people's lives, for example, maintaining biodiversity and abundant water sources. These customary rules are used as guidelines when they want to manage forests. The character's understanding of the sacred and forbidden areas can be seen in the following quote from Mawinei's novel.

Perjalanan ke kebun karet melintasi jalan setapak berbatu yang agak menanjak. Lalu harus melewati hutan rimba. Kebun karet itu terletak di areal tersendiri. Terpisah dari daerah pahumaan. Tidak mengusik wilayah hutan katuan larangan dan hutan katuan karamat [14].

The journey to the rubber plantations crosses a rocky path that is slightly uphill. Then you have to go through the jungle. The rubber plantation is located in a separate area. Separate from the area of pahumaan. Do not disturb the forest area of katuan larangan and katuan karamat [14].

In addition to forest management related to the division of sacred and forbidden areas, customary rules that help protect the environment are the prohibition against cutting down certain tree species. According to local knowledge, it is not permissible to cut down the tree because of its usefulness in supporting survival and protecting the forest as a source of livelihood. In Palas' novel, hanau and birik trees should not be cut down because they have benefits. For example, Hanau can be useful for making brown sugar from the tap water. Meanwhile, birik is believed to be useful for maintaining soil fertility. The illustration of the 
usefulness of these two trees so that they are not cut down can be seen in the following quote from Palas' novel.

Ada beberapa jenis pohon bermanfaat yang sengaja tidak ditebang, seperti pohon hanau dan birik. Daun muda pohon hanau mereka gunakan untuk perlengkapan membuat janur pada upacara aruh dan airnya disadap untuk dibuat gula habang. Sedang pohon birik juga dipelihara karena dalam ilmu pengetahuan orang bukit kulit pohonnya yang sudah lapuk dan daun layu yang jatuh ke tanah bermanfaat untuk meningkatkan kesuburan tanah [13].

Several types of useful trees are intentionally not cut, such as hanau and birik trees. The young leaves of hanau tree are used for equipment for making coconut leaves at the aruh ceremony and the water is tapped to make palm sugar. While birik trees are also maintained because in orang bukit local knowledge, weathered tree bark and wilted leaves that fall to the ground are useful for increasing soil fertility [13].

The customary rules of forest management continue because the Meratus Dayak people respect nature. Nature has become a source of livelihood. They are obliged to maintain its sustainability. The principle of reciprocity in nature management encourages the preservation of nature to be maintained. Customary rules accompanied by customary law sanctions for those who violate nature conservation also support the existence of forests. In Mawinei's novel, it is explained that the key to forest conservation is respect for nature by obeying the customary rules of forest management accompanied by customary law sanctions for those who violate it.
Jadi tak heran, perlakuan mereka dalam pemanfaatan hutan sangatlah berhati-hati. Menjaga betul kelestariannya. Ada sanksi hukum adat bila berani melanggar ketentuan ketika memanfaatkan hutan ini [14].

Arai's gaze was far away. The mountain afternoon wind blows breezily, playing their strands of hair. Slowly sinking into the contemplation of their lives who have only relied on the goodness of nature. They are the Meratus Dayak or Dayak Bukit who inherit the forests and nature of the Meratus Mountains. Since the time of their ancestors, their tribe has been friends with the wilderness. Their tradition is very venerating nature. So it's not surprising that their treatment of forest use is very careful. Take care of its sustainability. There are customary law sanctions if you dare to violate the provisions when utilizing this forest [14].

The Meratus Dayak community has customary rules in preserving nature that has been mutually agreed upon. The regulation relates to the division of forest management areas. Katuan keramat and katuan larangan are protected forests that should not be used carelessly because they are believed to be the resting place of ancestors. Forest utilization can be carried out in other areas, except in these two areas. These customary rules support their lives by maintaining water sources and biological wealth. The prohibition of cutting down certain tree species because of their usefulness in supporting life and maintaining soil fertility also contributes to the preservation of the Meratus forest.

In Pranoto's article entitled "The Role of Mother Language as a Pillar of Green Literature: Exploring the Philosophy of Local Wisdom Protecting the Earth of South Kalimantan" explores the role of the mother tongue in protecting the earth of South Kalimantan due to environmental destruction through local wisdom in proverbs that developed in the Banjar community [4]. This article explores the role of local culture, especially environmental ethics and tradisional rules in conserving the environment.

\section{CONCLUSION 5.1. Conclusion}

Ecocritical studies on the two novels, Palas by Aliman Syahrani and Mawinei by Eva Liana have described local culture related to environmental conservation based on environmental ethics and Dayak Meratus customary rules in preserving nature. 
Environmental ethics is manifested in respect for the Meratus Dayak community for nature through a close relationship with nature, for example, the ability to read natural signs that are believed to be able to describe events that occur in the future. Respect for nature is also seen in the farming system which is covered by a series of traditional rituals as an expression of supplication for the fertility of the soil and plants before sacrificing and gratitude for the abundant harvest in bawanang ritual or aruh ganal.

Customary rules in supporting forest conservation are described in Palas and Mawinei's novels through the rules for managing forest areas in katuan keramat dan katuan larangan. The protected forest area of katuan keramat should not be used because it is believed to be sacred as an ancestral burial area, while the management of katuan larangan is also limited because it is only allowed to use forest products, other than wood. In addition, the prohibition on the logging of certain tree species, such as hanau and birik, also supports Meratus' natural preservation.

\subsection{Suggestion}

Based on the research results, the two novels set in the Meratus Mountains contain wisdom that has educational value. The role of local Meratus Dayak culture in maintaining the natural existence of Meratus as a home and source of livelihood is very important as a form of environmental conservation. The local culture of Meratus Dayak community needs to be preserved in an effort to protect the nature of the Meratus Mountains in the midst of natural exploitation that threatens ecological destruction in the era of industrialization and capitalization.

\section{REFERENCES}

[1] Walhi, Masa Depan Ekologis di Tahun Politik, 2017.

[2] BNPB, Bencana Indonesia 2020, 2020.

[3] N. Dewi, Ekokritik dalam Sastra Indonesia: Kajian Sastra yang memihak, in: Proceedings of Adabiyyat, vol. 15, 2016.

[4] N. Pranoto, Peranan Bahasa Ibu sebagai Pilar Sastra Hijau Menggali Filosofi Kearifan Lokal Pelindung Bumi Kalimantan Selatan, 2015.

[5] S. Endraswara, Ekokritik Sastra. Yogyakarta, Morfalingua, 2016.

[6] D. R. Riana, Krisis Lingkungan di Kalimantan dalam Karya Puisi Kalimantan Rinduku yang Abadi, in: Proceedings of Genta Bahtera, vol. 6, 2020. dalam Pemali Banjar, in: Proceedings of Ecology of Language Literature, 2015.

[8] H. F. Glotfelty, Landmarks in Literary Ecology. Athens, The University of Georgia Press, 1996.

[9] G. Garrad, Ecocriticism, New York, Routledge, 2004.

[10] S. Harsono, Ekokritik: Kritik Sastra Berwawasan Lingkungan, in: Proceedings of Kaji. Sastra, vol. 32, 2008.

[11] K. T. Buell, Lawrence, Ursula, K. Heise, Literature and Environment, in: Proceedings of Annu. Rev. Environ. Resour, vol. 36, 2011.

[12] D. Damayanti, Meratus, Nyanyi Sunyi di Pegunungan Borneo, Yogyakarta, Lamalera, 2016.

[13] A. Syahrani, Palas, in: Proceedings of Banjarmasin: Forum Kajian Budaya Banjar Bekerja sama dengan Penerbit Pustaka Banua, 2004.

[14] E. Liana, Mawinei, Banjarbaru, Penerbit Zukzez Express, 2017. 